\title{
The Practice of Technological Pedagogical Content Knowledge of Teacher Educators in Education Colleges in Myanmar
}

\author{
Win Thinzarkyaw \\ Assistant Lecturer, Department of Educational Theory, Yankin Education College, Yangon, \\ Myanmar and PhD Candidate, School of Education, Central China Normal University, Wuhan, \\ China \\ ORCID: 0000-0002-3393-9802
}

Received: 13 Nov 2019

Accepted: 27 Nov 2019

Published: 17 Dec 2019

\begin{abstract}
The purpose of this study was to investigate the practice of technological pedagogical content knowledge (TPACK) of teacher educators $(\mathrm{N}=108)$ in three Education Colleges in Myanmar. A quantitative survey research design focusing on a set of questionnaire was used. The results showed that there were no significant differences in the TPACK-based practices of teacher educators in terms of their Education College, experience, degree, rank, department and gender. However, significant differences were unearthed in their practices of technological knowledge according to their experience and degree. Besides, by their ranks, significant differences were found in the practice of technological and content knowledge.
\end{abstract}

Keywords: teacher educators, technological pedagogical content knowledge, education colleges

\section{INTRODUCTION}

In the nineteenth century, the predominant notion was that strong subject matter knowledge was enough for teachers to be able to teach new content. However, this notion shifts with the awareness of the importance of pedagogical knowledge and knowledge of the content when it came to the early twentieth century. Towards the end of the twentieth century, perceptions about the knowledge of teacher was recognized as the combination of content and pedagogy, as well as the pedagogical content knowledge (PCK) described by the intersection of content and pedagogy (Angeli \& Valanides, 2015). However, in the twenty-first century, teaching requires considerably more than delivering subject matter knowledge to students, and student learning is considerably more than absorbing information for later retrieval. Therefore, knowledge of technology becomes an important aspect of overall teacher knowledge in this globalization age as one of the strengths of technology is to support student learning rather than as a tool to deliver the content. As a consequence, teachers not only need to know how to use information and communication technologies (ICT), but also have an awareness of the strategies to incorporate them into teaching a particular subject's content to enhance student learning.

\section{IMPORTANCE OF THE STUDY}

As a result of the speedy advances in information and communication technology area, and the demand to achieve the 21st century skills in this globalization age, global trends in higher 
education are moving towards using digital pedagogies (Goradia, 2018). It means that technology has already been using in teaching with the aim of improving students' engagement and achievement in their learning. Therefore, it is widely accepted that knowledge related to technology of education plays an important role in all aspects of teacher' knowledge.

As mentioned, technology has become an essential proficiency of teachers required in teaching at the higher education level. However, many professional development programs mostly emphasize on learning specific applications related to technology but rarely on how to approach the content by using technology. To remove this barrier, technological pedagogical content knowledge (TPACK) framework provides a way to integrate pedagogical, content, and technological knowledge in order to produce effective teaching with technology (Koehler \& Mishra, 2009).

Therefore, many research studies related to technological pedagogical content knowledge have been done during this decade. However, studies based on the TPACK theoretical framework have been mostly carried out with pre-service teachers, but researches conducted with the teacher educators participants are still limited till now, especially in higher education (Can, Erokten, \& Bahtiyar, 2017; Karaca, 2015; Keser, Yılmaz, \& Yılmaz, 2015; Kou, 2015; Özdemir, 2006). Moreover, the results of many studies that focused on the development of instruments related to TPACK confirmed TPACK framework and also the seven subscales of it (Kiray, 2016; Nordin \& Ariffin, 2016; Sahin, 2011). Furthermore, there were studies that tried to determine the factors which influence on teachers' TPACK levels. In addition, the results of many studies uncovered that gender and professional experience of teachers influenced their TPACK levels (Akturk \& Ozturk, 2019; Alqurashi, Gokbel, \& Carbonara, 2016; Jang \& Chang, 2016; Ozudogru \& Ozudogru, 2019).

Many studies related to teachers' pedagogical content knowledge have been done in Myanmar. Unfortunately, very few studies concerned with teachers' technological pedagogical content knowledge was carried out, especially in Education Colleges. Thus, this study was carried out with the aim of investigating the practice of teacher educators' technological pedagogical content knowledge in their profession in the context of Myanmar.

\section{REVIEW OF RELATED LITERATURE}

As technologies have gradually been integrated in teaching learning process, new technology integration models have been developed by many scholars. Among them, the framework that becomes popular after 2006 is technological pedagogical content knowledge (TPACK) developed by Mishra and Koehler (2006). They declared that the three main components of teachers' knowledge: content, pedagogy, and technology are at the heart of TPACK as this framework was developed based on pedagogical content knowledge (PCK) of Shulman (1986). Shulman (1987) asserted that among the seven categories of teacher's knowledge: content knowledge, general pedagogical knowledge, curriculum knowledge, pedagogical content knowledge, knowledge of learners and their characteristics, knowledge of educational contexts, and knowledge of educational ends, purposes, and values, and their philosophical and historical grounds, pedagogical content knowledge is of special interest as it represents the unique bodies of knowledge for teaching that distinguishes teachers from content specialists. Therefore, pedagogical content knowledge was defined as:

"... the blending of content and pedagogy into an understanding of how particular topics, problems, or issues are organized, represented, and adapted to the diverse interests and abilities of learners, and presented for 
instruction. It is the category most likely to distinguish the understanding of the content specialist from that of the pedagogue" (Shulman, 1987).

The definition of pedagogical content knowledge (PCK) by Loughran, Berry, and Mulhall (2012) was that it is the knowledge about how to teach particular content in particular ways with the aim of strengthening student understanding that teachers gradually develop by means of experience. They also mentioned that PCK of teachers may be different from each other depending on the teaching context, content, and their experience but it is, nevertheless, a corner stone of teachers' professional knowledge and expertise.

Angeli and Valanides (2015) stated that TPACK framework characterizes the knowledge that teachers focus on, when designing and implementing curriculum and instruction, while guiding the way of thinking and learning of their students with digital technologies in various content areas. Therefore, TPACK model of Koehler and Mishra (2009) describes teacher's knowledge as a result of combination of seven knowledge dimensions: technological knowledge (TK), pedagogical knowledge (PK), content knowledge (CK), pedagogical content knowledge (PCK), technological content knowledge (TCK), technological pedagogical knowledge (TPK), and technological pedagogical content knowledge (TPCK) that are equally important in this model.

Technological knowledge (TK) is knowledge about technologies ranging from standard to digital technologies, and involves the skills required to operate particular technologies (Mishra \& Koehler, 2006).

Pedagogical knowledge (PK) includes the knowledge of strategies and principles of teaching, classroom management and organization in education (Shulman, 1987).

Content knowledge (CK) is the amount of the actual knowledge and organization in the mind of the teacher (Shulman, 1986). It is the depth and breadth of knowledge in a specific content area (Doering, Veletsianos, Scharber, \& Miller, 2009).

Pedagogical content knowledge (PCK) is the combination of the rich knowledge of pedagogy and content together, each shaping and interacting with the other so that what is taught, and how it is constructed are purposefully created to ensure that the content is better understood by students in a given context because of the way the teaching has been organized, planned, analyzed and presented (Loughran et al., 2012).

Technological content knowledge (TCK) is the knowledge of various technologies and their uses in teaching depending on the nature of the content and to change the way learners understand the concepts (Padmavathi, 2017).

Technological pedagogical knowledge (TPK) is the knowledge of using pedagogical strategies appropriate to technological tools and the knowledge of how teaching might change as a result of using particular technologies (Mishra \& Koehler, 2006).

Technological pedagogical content knowledge (TPCK) is the knowledge teachers rely on while guiding their students' thinking and learning of specific content areas with particular technologies efficiently (Mishra \& Koehler, 2006). 


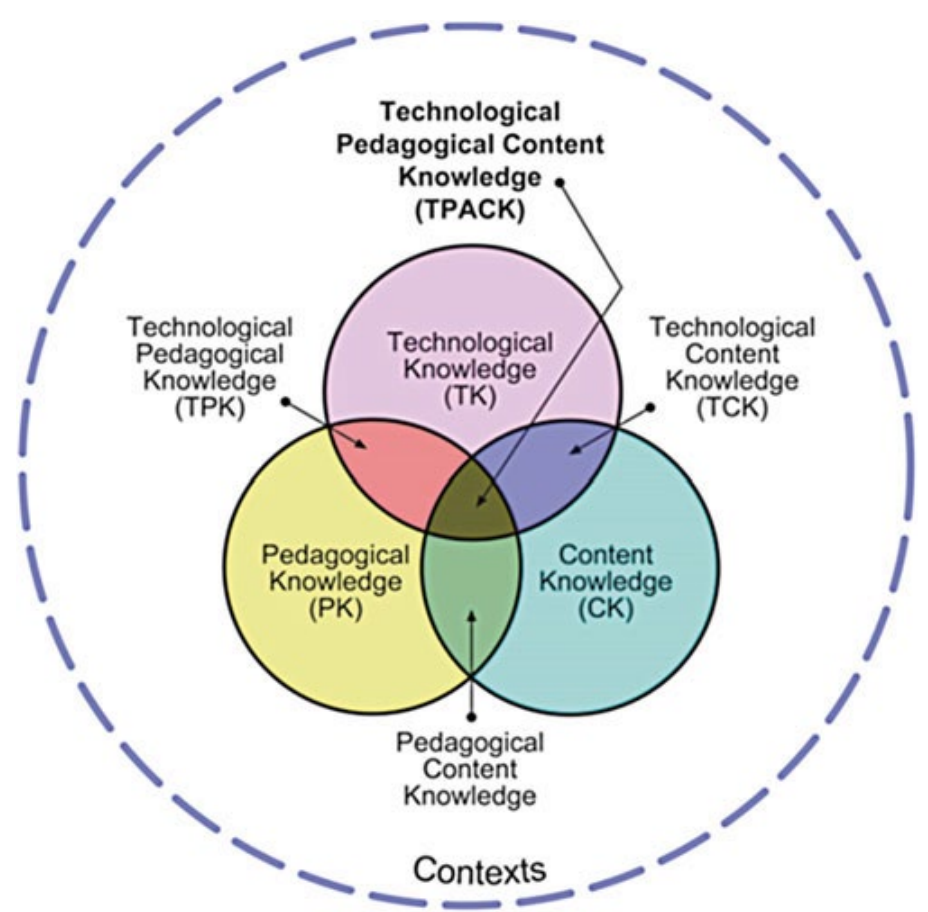

Figure 1. The TPACK framework and its knowledge components (Koehler \& Mishra, 2009)

According to Mishra and Koehler, (2006), TPACK framework contributes an analytic framework and categorization schemes for the analysis of teacher knowledge and its evolution. What is more, it imparts how to design pedagogical strategies and an analytic ways to examine the changes in educators' knowledge about successful teaching with technology. Additionally, it allows not only to understand about the effective teaching with technology but also to make predictions and assumptions about contexts under which such good teaching will occur. Moreover, it offers the ways of analysis and development of a complex phenomenon of technology integration and offers considerable options for further researches in teacher education, teacher professional development, and teachers' use of technology (Koehler \& Mishra, 2009).

\section{PURPOSES}

The main purpose of this study was to investigate the practice of technological pedagogical content knowledge of teacher educators in Education Colleges in Myanmar.

\section{RESEARCH QUESTIONS}

1. What are the practices of teacher educators' technological pedagogical content knowledge in Education Colleges in Myanmar?

2. Do the practices of teacher educators' technological pedagogical content knowledge vary with respect to their (1) Education College (2) teaching experience (3) degree (4) rank (5) department, and (6) gender? 


\section{RESEARCH METHOD}

\section{Research Design}

The research design applied in this study is a descriptive survey in which the quantitative data were collected by a set of predetermined questionnaire.

\section{Scope of the Study}

The following points indicate the scope of the study.

- This study was carried out in three education colleges in Yangon Region, Myanmar.

- The participants in this study were teacher educators from three education colleges in Yangon Region, Myanmar.

\section{Sample of the Study}

The sample of the study was comprised of all teacher educators from three education colleges - Thingangyun (TEC), Yankin (YEC), Hlegu (HEC) in Yangon Region, Myanmar, except those who were engaged in their class schedules during the survey. The sample can be organized as shown in Table 1.

Table 1. Demographic data of participants or teacher educators

\begin{tabular}{|c|c|c|c|}
\hline Category & Subcategories & Number & Total \\
\hline \multirow{3}{*}{ Education College } & Thingangyun (TEC) & 35 & \multirow{3}{*}{108} \\
\hline & Yankin (YEC) & 41 & \\
\hline & Hlegu (HEC) & 32 & \\
\hline \multirow{2}{*}{ Gender } & Male & 12 & \multirow{2}{*}{108} \\
\hline & Female & 96 & \\
\hline \multirow{4}{*}{ Teaching Service } & 1-10 years & 35 & \multirow{4}{*}{108} \\
\hline & $11-20$ years & 38 & \\
\hline & $21-30$ years & 9 & \\
\hline & Above 31 years & 26 & \\
\hline \multirow{4}{*}{ Degree } & Master of Arts/ Science (MA, MSc) & 46 & \multirow{4}{*}{108} \\
\hline & Bachelor of Education (BEd) & 38 & \\
\hline & Master of Education (MEd) & 20 & \\
\hline & Doctor of Philosophy (PhD) & 4 & \\
\hline \multirow{3}{*}{ Rank } & Tutor & 33 & \multirow{3}{*}{108} \\
\hline & Assistant Lecturer & 18 & \\
\hline & Lecturer & 57 & \\
\hline \multirow{2}{*}{ Department } & Academic & 53 & \multirow{2}{*}{108} \\
\hline & Education & 55 & \\
\hline
\end{tabular}

\section{Instruments}

The instruments used in this study were a predetermined questionnaire which was comprised of two parts. The first part was related to some demographic data such as Education colleges and departments where the participants are working currently, gender, their teaching experiences, their educational qualifications and ranks. The second part of the questionnaire was composed of 45 items constructed by Ismail Sahin (2011) based on Mishra and Koehler (2006) model: 14 items were related to technological knowledge, 6 items to pedagogy knowledge, 6 items to content knowledge, 4 items to technological pedagogical knowledge, 7 items to pedagogical content knowledge, 3 items to technological content knowledge and 5 
items were related to technological pedagogical content knowledge. The rating scale for the response was set in 5-point Likert as "never", "rarely", "sometimes", "often" and "always".

\section{Procedure}

First, the relevant literature was reviewed. Then, the instrument questionnaire constructed by Ismail Sahin (2011) based on Mishra and Koehler (2006) model was modified and translated into Myanmar language. Three teacher educators (a retired professor of education, an associate professor of education from the Methodology Department, Sagaing University of Education, and an assistant lecturer from the Methodology Department, Yankin Education College) were requested for expert review for the validation of the questionnaire. After that, the study was piloted with 20 teacher educators in Thingangyun Education College. The items were modified and the data obtained from the pilot study were calculated by the Cronbach's alpha coefficient. The internal consistency for the questionnaire was (0.785). The main survey was completed in three Education Colleges in Yangon Region, Myanmar in March, 2019.

\section{Analysis of the Data}

The data were analyzed by calculating the means of each dimension in order to determine the practice of technological pedagogical content knowledge of teacher educators from the selected education colleges. Moreover, the dependent variables were normally distributed within each group according to the result of a Kolmogorov-Smirnov test. Therefore, descriptive statistics, one-way ANOVA, Post Hoc Multiple Comparison Test and Independent Samples $t$ Test were used to analyze whether there is a significant difference in the practice of technological pedagogical content knowledge among teacher educators in terms of their Education College, teaching service, degree, rank, department and gender.

\section{RESEARCH FINDINGS}

\section{Findings of the Practice of Teacher Educators' TPACK in the Selected Education Colleges}

To determine the practice of teacher educators' TPACK, descriptive data (mean and standard deviation) of the TPACK survey scores were calculated. The results of the analysis were given in Table 2.

Table 2. Means and standard deviations of the practice of each dimension of teacher educators' TPACK

\begin{tabular}{llll}
\hline Dimension & $\mathbf{N}$ & $\overline{\mathbf{X}}$ & SD \\
\hline Technological Knowledge (TK) & 108 & 2.58 & .878 \\
\hline Pedagogical Knowledge (PK) & 108 & 3.82 & .745 \\
\hline Content Knowledge (CK) & 108 & 3.67 & .641 \\
\hline Technological Pedagogical Knowledge (TPK) & 108 & 3.32 & .722 \\
\hline Pedagogical Content Knowledge (PCK) & 108 & 3.96 & .675 \\
\hline Technological Content Knowledge (TCK) & 108 & 3.43 & .957 \\
\hline Technological Pedagogical Content Knowledge (TPCK) & 108 & 3.11 & .726 \\
\hline
\end{tabular}

The comparison of means of each dimension of teacher educators' TPACK indicated that the means of technology related dimensions (TK, TPK, TCK and TPCK) were lower than other dimensions (see Table 2). Among them, the mean of technology knowledge dimension ( $\bar{X}=2.58$ ) was the lowest whilst that of pedagogical content knowledge dimension $(\bar{X}=3.96)$ was the highest compared to others. Moreover, the means of pedagogical knowledge dimension and 
technological pedagogical content knowledge dimension stood at the second highest and lowest positions ( $\bar{X}=3.82$ and $\bar{X}=3.11$ ) respectively whereas content knowledge, technological content knowledge and technological pedagogical knowledge followed subsequently. It means that teacher educators rarely applied their knowledge of technology in their teaching and other dimensions of TPACK were utilized on some occasions as their means were around 3.0.

\section{Findings of the Practice of TPACK among the Teacher Educators according to their Education Colleges}

In order to compare the selected education colleges on the practice of teacher educators' TPACK, descriptive data (mean and standard deviation) of the TPACK survey scores were calculated. The participants were divided into three groups according to their education colleges (group 1; Thingangyun Education College, group 2; Yankin Education College and group 3; Hlegu Education College). The results of the analysis were given in Table 3.

Table 3. Means and standard deviations of three education colleges

\begin{tabular}{cccccccccc}
\hline EC & $\mathbf{N}$ & $\begin{array}{c}\text { TK } \\
(\overline{\mathbf{X}}, \mathbf{S D})\end{array}$ & $\begin{array}{c}\text { PK } \\
(\overline{\mathbf{X}}, \mathbf{S D})\end{array}$ & $\begin{array}{c}\text { CK } \\
(\overline{\mathbf{X}}, \mathbf{S D})\end{array}$ & $\begin{array}{c}\text { TPK } \\
(\overline{\mathbf{X}}, \mathbf{S D})\end{array}$ & $\begin{array}{c}\text { PCK } \\
(\overline{\mathbf{X}}, \mathbf{S D})\end{array}$ & $\begin{array}{c}\text { TCK } \\
(\overline{\mathbf{X}}, \mathbf{S D})\end{array}$ & $\begin{array}{c}\text { TPCK } \\
(\overline{\mathbf{X}}, \mathbf{S D})\end{array}$ & $\begin{array}{c}\text { TPACK } \\
(\overline{\mathbf{X}}, \text { SD })\end{array}$ \\
\hline TEC & 35 & $\mathbf{2 . 7 1}, .928$ & $3.78, .806$ & $3.69, .638$ & $3.26, .838$ & $3.95, .592$ & $3.34,1.021$ & $3.05, .758$ & $3.40, .577$ \\
\hline YEC & 41 & $2.67, .879$ & $4.00, .706$ & $3.74, .635$ & $3.50, .597$ & $4.08, .613$ & $3.51, .907$ & $3.21, .705$ & $3.53, .451$ \\
\hline HEC & 32 & $2.32, .788$ & $3.63, .691$ & $3.56, .659$ & $3.15, .701$ & $3.82, .813$ & $3.41, .968$ & $3.04, .723$ & $3.27, .542$ \\
\hline Total & 108 & $2.58, .878$ & $3.82, .745$ & $3.67, .641$ & $3.32, .722$ & $3.96, .675$ & $3.43, .957$ & $3.11, .726$ & $3.41, .528$ \\
\hline
\end{tabular}

In the dimensions of PK, CK, TPK, PCK, TCK and TPCK, the means of YEC were the highest among the selected education colleges while the mean of TEC was the highest in the dimension of TK (see Table 3). Furthermore, the means of TEC stayed on the second highest status in other dimensions except the dimension of TCK. The point is that the mean of HEC stood third as its means were at the lowest in other dimensions. To sum up, the total mean (TPACK) of YEC $(\bar{X}=3.53)$ outperformed those of TEC and HEC ( $\bar{X}=3.40$ and $\bar{X}=3.27)$ respectively. Therefore, it can be interpreted that teacher educators from Yankin Education College applied their TPACK in their profession more than those of Thingangyun and Helgu Education Colleges. Moreover, they rarely applied technological knowledge in their teaching as the means of three education colleges resulted below 3.0.

One way ANOVA was used to explore the significant level of the utilization of Teacher Educators' TPACK among the selected Education Colleges.

Table 4 showed that there was no significant difference among the selected Education Colleges in the practice of teacher educators' TPACK, $F(2,105)=2.189, p=.117$. Moreover, no statistically significant difference was found among these three Education Colleges in all the dimensions of TPACK. Therefore, it can be concluded that the application levels of TPACK among the teacher educators of the selected Education Colleges were almost the same. 
Table 4. ANOVA results comparing the selected education colleges on applying teacher educators' TPACK

\begin{tabular}{|c|c|c|c|c|c|c|}
\hline & & Sum of Squares & $d f$ & Mean Square & $\mathbf{F}$ & Sig. \\
\hline \multirow{3}{*}{ TK } & Between Groups & 3.100 & 2 & 1.550 & \multirow{3}{*}{2.050} & \multirow{3}{*}{.134} \\
\hline & Within Groups & 79.397 & 105 & .756 & & \\
\hline & Total & 82.497 & 107 & & & \\
\hline \multirow{3}{*}{ PK } & Between Groups & 2.609 & 2 & 1.034 & \multirow{3}{*}{2.410} & \multirow{3}{*}{.095} \\
\hline & Within Groups & 56.843 & 105 & .541 & & \\
\hline & Total & 59.451 & 107 & & & \\
\hline \multirow{3}{*}{ CK } & Between Groups & .591 & 2 & .296 & \multirow{3}{*}{.715} & \multirow{3}{*}{.491} \\
\hline & Within Groups & 43.409 & 105 & .413 & & \\
\hline & Total & 44.000 & 107 & & & \\
\hline \multirow{3}{*}{ TPK } & Between Groups & 2.379 & 2 & 1.189 & \multirow{3}{*}{2.341} & \multirow{3}{*}{.101} \\
\hline & Within Groups & 53.350 & 105 & .508 & & \\
\hline & Total & 55.729 & 107 & & & \\
\hline \multirow{3}{*}{ PCK } & Between Groups & 1.249 & 2 & .625 & \multirow{3}{*}{1.383} & \multirow{3}{*}{.255} \\
\hline & Within Groups & 47.438 & 105 & .452 & & \\
\hline & Total & 48.687 & 107 & & & \\
\hline \multirow{3}{*}{ TCK } & Between Groups & .559 & 2 & .280 & \multirow{3}{*}{.301} & \multirow{3}{*}{.740} \\
\hline & Within Groups & 97.404 & 105 & .928 & & \\
\hline & Total & 97.963 & 107 & & & \\
\hline \multirow{3}{*}{ TPCK } & Between Groups & .734 & 2 & .367 & \multirow{3}{*}{.693} & \multirow{3}{*}{.502} \\
\hline & Within Groups & 55.617 & 105 & .530 & & \\
\hline & Total & 56.351 & 107 & & & \\
\hline \multirow{3}{*}{ TPACK } & Between Groups & 1.192 & 2 & .596 & \multirow{3}{*}{2.189} & \multirow{3}{*}{.117} \\
\hline & Within Groups & 28.588 & 105 & .272 & & \\
\hline & Total & 29.780 & 107 & & & \\
\hline
\end{tabular}

\section{Findings of the Practice of Teacher Educators' TPACK in terms of Teaching Service}

In order to make a comparison on the application levels of TPACK among the teacher educators in terms of their teaching experience, descriptive data was calculated. The participants were divided into four groups according to their teaching experience (group 1; 1-10 years, group 2; 11-20 years, group 3; 21-30 years and group 4; above 31). The results were shown in Table 5.

Table 5. Means and standard deviations of the teacher educators in terms of their teaching service

\begin{tabular}{|c|c|c|c|c|c|c|c|c|c|}
\hline $\begin{array}{c}\text { Teaching } \\
\text { Service }\end{array}$ & $\mathbf{N}$ & $\begin{array}{c}\text { TK } \\
(\overline{\mathrm{X}}, \mathrm{SD})\end{array}$ & $\begin{array}{c}\text { PK } \\
(\bar{X}, S D)\end{array}$ & $\begin{array}{c}\mathrm{CK} \\
(\overline{\mathrm{X}}, \mathrm{SD})\end{array}$ & $\begin{array}{c}\text { TPK } \\
(\bar{X}, S D)\end{array}$ & $\begin{array}{c}\mathrm{PCK} \\
(\overline{\mathrm{X}}, \mathrm{SD})\end{array}$ & $\begin{array}{c}\text { TCK } \\
(\bar{X}, S D)\end{array}$ & $\begin{array}{l}\text { TPCK } \\
(\overline{\mathrm{X}}, \mathrm{SD})\end{array}$ & $\begin{array}{l}\text { TPACK } \\
(\bar{X}, S D)\end{array}$ \\
\hline 1-10 Yrs & 35 & $2.99, .718$ & $3.92, .574$ & $3.66, .506$ & $3.28, .742$ & $3.78, .547$ & $3.26, .987$ & $2.90, .727$ & $3.40, .519$ \\
\hline $11-20$ Yrs & 38 & $2.74, .859$ & $3.78, .884$ & $3.72, .715$ & $3.39, .764$ & $3.99, .649$ & $3.56, .949$ & $3.17, .698$ & $3.48, .576$ \\
\hline $21-30 \mathrm{Yrs}$ & 9 & $1.87, .606$ & $3.80, .655$ & $3.85, .704$ & $3.50, .625$ & $4.08, .866$ & $3.63, .889$ & $3.51, .736$ & $3.46, .500$ \\
\hline Above 31 Yrs & 26 & $2.04, .796$ & $3.76, .785$ & $3.53, .680$ & $3.20, .675$ & $4.13, .770$ & $3.38, .960$ & $3.16, .716$ & $3.31, .485$ \\
\hline Total & 108 & $2.58, .878$ & $3.82, .745$ & $3.67, .641$ & $3.32, .722$ & $3.96, .675$ & $3.43, .957$ & $3.11, .726$ & $3.41, .528$ \\
\hline
\end{tabular}

The results of Table 5 revealed that the means of teacher educators whose teaching service falls between 1 and 20 years were found to be at the top in the dimensions of TK and PK though their means were at the lowest in the dimensions of TCK, PCK and TPCK. Interestingly, for those whose had between 11 and 20 years of teaching service, their means never stayed the highest and lowest but the means of TK, PK and TPK dimensions were at the second highest and the others at the second lowest. Moreover, while the means of those whose teaching service was between 21 and 30 years showed the highest in the dimensions of CK, TPK, TCK and TPCK, the means of those who had at least 31 years of teaching experience had the highest PCK compared to others. 
However, their means in the dimension of CK, PK and TPK were the lowest. One interesting point is that the means of PCK dimension increased according to the increment in their teaching experience.

Thus, in general, it can be interpreted that young teacher educators though they had the less teaching experience than others utilized the TPACK more than others However, it was revealed that PCK increased gradually with respect to the year of teaching experience and the young teacher educators had much more TK than others.

In order to investigate the statistically significant level in comparing teacher educators by means of teaching service on applying TPACK, one way ANOVA and Post Hoc Multiple Comparison Tests were used.

The results highlighted that there was no statistically significant difference among the teacher educators by their teaching service in the application of TPACK, $F(3,104)=.532, p=.661$. However, statistically significant difference was found among those in only one dimension of technological knowledge $(T K), F(3,104)=10.299, p=.000$ (see Table 6). The effect size, calculated using eta squared, was .2. Post hoc Tukey HSD tests also indicated that significant differences were found among the groups $(\overline{\mathrm{X}}=2.99,1-10$ Yrs, $\overline{\mathrm{X}}=2.79,11-20 \mathrm{Yrs}, \overline{\mathrm{X}}=1.87,21-30$ Yrs and $\bar{X}=2.04$, above 30 Yrs $)$ in TK $(p<.05)$ except between the groups of 1-10 years and 1120 years. It means that the practice of teacher educators' TPACK did not differ according to their teaching experience even though they had different practice of technological knowledge in their teaching.

Table 6. ANOVA results comparing teacher educators in terms of teaching service on the exploitation of TPACK

\begin{tabular}{|c|c|c|c|c|c|c|}
\hline & & Sum of Squares & df & Mean Square & $\mathbf{F}$ & Sig. \\
\hline \multirow{3}{*}{ Mean TK } & Between Groups & 18.896 & 3 & 6.299 & 10.299 & $.000^{* * *}$ \\
\hline & Within Groups & 63.601 & 104 & .612 & & \\
\hline & Total & 82.497 & 107 & & & \\
\hline \multirow{3}{*}{ Mean PK } & Between Groups & .526 & 3 & .175 & .309 & .818 \\
\hline & Within Groups & 58.925 & 104 & .567 & & \\
\hline & Total & 59.451 & 107 & & & \\
\hline \multirow{3}{*}{ Mean CK } & Between Groups & .886 & 3 & .295 & .712 & .547 \\
\hline & Within Groups & 43.114 & 104 & .415 & & \\
\hline & Total & 44.000 & 107 & & & \\
\hline \multirow{3}{*}{ Mean TPK } & Between Groups & .926 & 3 & .309 & .586 & .626 \\
\hline & Within Groups & 54.803 & 104 & .527 & & \\
\hline & Total & 55.729 & 107 & & & \\
\hline \multirow{3}{*}{ Mean PCK } & Between Groups & 2.071 & 3 & .690 & 1.540 & .209 \\
\hline & Within Groups & 46.617 & 104 & .448 & & \\
\hline & Total & 48.687 & 107 & & & \\
\hline \multirow{3}{*}{ Mean TCK } & Between Groups & 2.112 & 3 & .704 & .764 & .517 \\
\hline & Within Groups & 95.851 & 104 & .922 & & \\
\hline & Total & 97.963 & 107 & & & \\
\hline \multirow{3}{*}{ Mean TPCK } & Between Groups & 3.257 & 3 & 1.086 & 2.127 & .101 \\
\hline & Within Groups & 53.094 & 104 & .511 & & \\
\hline & Total & 56.351 & 107 & & & \\
\hline \multirow{3}{*}{ Total Mean TPACK } & Between Groups & .450 & 3 & .150 & .532 & .661 \\
\hline & Within Groups & 29.330 & 104 & .282 & & \\
\hline & Total & 29.780 & 107 & & & \\
\hline
\end{tabular}

Note. ${ }^{* * *} p<.001$ 


\section{Findings of the Practice of Teacher Educators' TPACK in terms of their Degree}

In order to compare the teacher educators' application level of TPACK according to their different degrees at the university, the analysis of descriptive data was made where the participants were divided into four groups according to their respective degrees: group 1; MA/MSc degree holders, group 2; BEd degree holders, group 3; MEd degree holders and group 4; PhD degree holders. The result can be seen in Table 7.

Table 7. Means and standard deviations of teacher educators by means of their degree

\begin{tabular}{|c|c|c|c|c|c|c|c|c|c|}
\hline Degree & $\mathbf{N}$ & $\begin{array}{c}\text { TK } \\
(\overline{\mathrm{X}}, \mathrm{SD}) \\
\end{array}$ & $\begin{array}{c}\text { PK } \\
(\overline{\mathrm{X}}, \mathrm{SD}) \\
\end{array}$ & $\begin{array}{c}\mathrm{CK} \\
(\overline{\mathrm{X}}, \mathrm{SD}) \\
\end{array}$ & $\begin{array}{c}\text { TPK } \\
(\overline{\mathrm{X}}, \mathrm{SD}) \\
\end{array}$ & $\begin{array}{c}\text { PCK } \\
(\overline{\bar{X}}, \text { SD })\end{array}$ & $\begin{array}{c}\text { TCK } \\
(\overline{\mathrm{X}}, \mathrm{SD}) \\
\end{array}$ & $\begin{array}{c}\text { TPCK } \\
(\overline{\mathrm{X}}, \mathrm{SD}) \\
\end{array}$ & $\begin{array}{l}\text { TPACK } \\
(\bar{X}, S D) \\
\end{array}$ \\
\hline MA/MSc & 46 & $2.77, .717$ & $3.87,746$ & $3.64, .626$ & $3.29, .713$ & $3.86, .586$ & $3.51,1.063$ & $2.93, .701$ & $3.41, .534$ \\
\hline $\mathrm{BEd}$ & 38 & $2.21, .812$ & $3.70, .752$ & $3.55, .737$ & $3.22, .757$ & $3.91, .848$ & $3.32, .958$ & $3.19, .747$ & $3.30, .541$ \\
\hline MEd & 20 & $2.80,1.088$ & $3.89, .742$ & $3.83,433$ & $3.46, .685$ & $4.29, .433$ & $3.47,721$ & $3.34,726$ & $3.58, .468$ \\
\hline $\mathrm{PhD}$ & 4 & $2.79,1.211$ & $4.04,821$ & $4.25, .289$ & $3.88, .479$ & $3.89, .317$ & $3.25, .877$ & $3.20, .542$ & $3.61, .486$ \\
\hline Total & 108 & $2.58, .878$ & $3.82,745$ & $3.67, .641$ & $3.32, .722$ & $3.96, .675$ & $3.43, .957$ & $3.11, .726$ & $3.41, .528$ \\
\hline
\end{tabular}

According to Table 7, the means of teacher educators holding PhD degree were the highest in the dimensions of PK, CK and TPK whilst the means of those BEd degree holders were at the lowest in those dimensions in addition to TK. Moreover, in the dimensions of TK, PCK and TPCK, the means of MEd degree holders stood at the peak and remained at the second highest in other dimensions except TCK where the means of those (MA/ MSc degree holders) were the highest and PhD degree holders' means were at the bottom. In short, the total mean (TPACK) of PhD degree holders ( $\bar{X}=3.61$ ) exceed others which was followed by the means of MEd, MA/MSc and BEd degree holders successively $(\bar{X}=3.58, \bar{X}=3.41$ and $\bar{X}=3.30)$ respectively. Therefore, it can be assumed that teacher educators who attained the higher educational level applied TPACK more than those of lower level attainment.

To find out the statistically significant difference in the practice of TPACK among the teacher educators in terms of their respective major, one way ANOVA and Post Hoc Multiple Comparison Tests were computed.

Table 8 uncovered no statistically significant difference among teacher educators' application of TPACK in terms of their respective degrees, $F(3,104)=1.503, p=.218$. Nevertheless, there was statistically significant difference among those in the dimension of technological knowledge, $F$ $(3,104)=3.741, p=.013$, but none was found in other dimensions. The effect size, calculated using eta squared, was .09. Moreover, as a result of Post hoc Tukey HSD tests, significant differences were found between the groups of BEd degree holders $(\bar{X}=2.21)$ and MA/MSc degree holders $(\overline{\mathrm{X}}=2.77)$ in TK $(p<.05)$, but not in other groups. Thus, it can be assumed that teacher educators had no difference in applying TPACK according to their different degrees but they had different background knowledge and application levels concerning with technological knowledge. 
Table 8. ANOVA table comparing teacher educators' TPACK with respect to their degree

\begin{tabular}{|c|c|c|c|c|c|c|}
\hline & & Sum of Squares & df & Mean Square & $\mathbf{F}$ & Sig. \\
\hline \multirow{3}{*}{ Mean TK } & Between Groups & 8.035 & 3 & 2.678 & 3.741 & $.013^{*}$ \\
\hline & Within Groups & 74.462 & 104 & .716 & & \\
\hline & Total & 82.497 & 107 & & & \\
\hline \multirow{3}{*}{ Mean PK } & Between Groups & .984 & 3 & .328 & .583 & .627 \\
\hline & Within Groups & 58.468 & 104 & .562 & & \\
\hline & Total & 59.451 & 107 & & & \\
\hline \multirow{3}{*}{ Mean CK } & Between Groups & 2.479 & 3 & .826 & 2.070 & .109 \\
\hline & Within Groups & 41.521 & 104 & .399 & & \\
\hline & Total & 44.000 & 107 & & & \\
\hline \multirow{3}{*}{ Mean TPK } & Between Groups & 2.038 & 3 & .679 & 1.316 & .273 \\
\hline & Within Groups & 53.691 & 104 & .516 & & \\
\hline & Total & 55.729 & 107 & & & \\
\hline \multirow{3}{*}{ Mean PCK } & Between Groups & 2.759 & 3 & .920 & 2.083 & .107 \\
\hline & Within Groups & 45.928 & 104 & .442 & & \\
\hline & Total & 48.687 & 107 & & & \\
\hline \multirow{3}{*}{ Mean TCK } & Between Groups & .979 & 3 & .326 & .350 & .789 \\
\hline & Within Groups & 96.984 & 104 & .933 & & \\
\hline & Total & 97.963 & 107 & & & \\
\hline \multirow{3}{*}{ Mean TPCK } & Between Groups & 2.743 & 3 & .914 & 1.774 & .157 \\
\hline & Within Groups & 53.608 & 104 & .515 & & \\
\hline & Total & 56.351 & 107 & & & \\
\hline \multirow{3}{*}{ Total Mean TPACK } & Between Groups & 1.237 & 3 & .412 & 1.503 & .218 \\
\hline & Within Groups & 28.543 & 104 & .274 & & \\
\hline & Total & 29.780 & 107 & & & \\
\hline
\end{tabular}

Note. ${ }^{*} p<.05$

\section{Findings of the Practice of Teacher Educators' TPACK in terms of Rank}

Descriptive data analysis was carried out to compare the practice of TPACK of teacher educators in terms of their position. The participants were divided into three groups according to their ranks: group 1; tutors, group 2; assistant lecturers and group 3; lecturers. A tutor is in the lowest position or rank in teaching profession at the higher education level. An assistant lecturer is higher in the position than a tutor and a lecturer is higher than an assistant lecturer. The result was displayed in Table 9.

Table 9. Means and standard deviations of teacher educators by means of their rank

\begin{tabular}{cccccccccc}
\hline Rank & $\mathbf{N}$ & $\begin{array}{c}\text { TK } \\
(\overline{\mathbf{X}}, \mathbf{S D})\end{array}$ & $\begin{array}{c}\mathbf{P K} \\
(\overline{\mathbf{X}}, \mathbf{S D})\end{array}$ & $\begin{array}{c}\mathbf{C K} \\
(\overline{\mathbf{X}}, \mathbf{S D})\end{array}$ & $\begin{array}{c}\text { TPK } \\
(\overline{\mathbf{X}}, \mathbf{S D})\end{array}$ & $\begin{array}{c}\text { PCK } \\
(\overline{\mathbf{X}}, \mathbf{S D})\end{array}$ & $\begin{array}{c}\text { TCK } \\
(\overline{\mathbf{X}}, \mathbf{S D})\end{array}$ & $\begin{array}{c}\text { TPCK } \\
(\overline{\mathbf{X}}, \mathbf{S D})\end{array}$ & $\begin{array}{c}\text { TPACK } \\
(\overline{\mathbf{X}}, \mathbf{S D})\end{array}$ \\
\hline $\begin{array}{c}\text { Tutor } \\
\begin{array}{c}\text { Assistant- } \\
\text { Lecturer }\end{array}\end{array}$ & $\mathbf{3 3}$ & $\mathbf{2 . 9 2 , . 7 4 3}$ & $3.88, .599$ & $3.58, .514$ & $3.27, .711$ & $3.77, .554$ & $3.22, .953$ & $2.93, .798$ & $3.37, .505$ \\
\hline Lecturer & 57 & $2.62, .866$ & $3.90, .741$ & $4.01, .665$ & $3.63, .729$ & $4.21, .546$ & $3.59, .890$ & $3.31, .652$ & $3.61, .471$ \\
\hline Total & 108 & $2.58, .878$ & $3.76, .826$ & $3.61, .674$ & $3.25, .713$ & $3.99, .749$ & $3.49, .976$ & $3.15, .693$ & $3.37, .551$ \\
\hline
\end{tabular}

The results of the analysis disclosed that the mean of tutors overtook that of assistant lecturer and lecturer in TK dimension. Likewise, the mean of assistant lecturer outdid that of tutors and lecturers in all the dimensions except TK whereas the mean of tutors was at the bottommost in the dimensions of CK, PCK, TCK and TPCK, and the means of lecturers were also at the lowest level in the dimensions of TK, PK and TPK. All things considered, the mean of assistant lecturer $(\bar{X}=3.61)$ outperformed others who had the same mean $(\bar{X}=3.37)$. Hence, it can be interpreted 
that assistant lecturers used their TPACK in their profession more than others while the applications of TPACK of tutors and lecturers were at the same level.

One way ANOVA and Post hoc Multiple Comparison Test were used with the aim of exploring the statistically significant difference among the application of TPACK in terms of their ranks in Education Degree Colleges.

The results of the analysis revealed that there was no statistically significant difference among the teacher educators' application level of TPACK with respect to their rank, $F(2,105)=1,524$, $p=.223$. But, statistically significant differences among those were found in the dimensions of technological knowledge and content knowledge, $F(2,105)=4.333, p=.016$ and $F(2,105)=$ $3.231, p=.043$ respectively (see Table 10 ). The effect sizes, calculated using eta squared, were .07 in TK and .05 in CK. Additionally, the result of Post hoc Tukey HSD tests showed that there were significant differences only between the groups of tutors $(\overline{\mathrm{X}}=2.92)$ and lecturers $(\overline{\mathrm{X}}=2.37)$ in TK $(p<.05)$. Therefore, it can be interpreted that the application level of TPACK among teacher educators did not differ in terms of their rank but their technological knowledge and content knowledge were put differently into practice.

Table 10. ANOVA table comparing the practice of teacher educators' TPACK in terms of their rank

\begin{tabular}{|c|c|c|c|c|c|c|}
\hline & & Sum of Squares & df & Mean Square & $\mathbf{F}$ & Sig. \\
\hline \multirow{3}{*}{ Mean TK } & Between Groups & 6.289 & 2 & 3.144 & 4.333 & $.016^{*}$ \\
\hline & Within Groups & 76.208 & 105 & .726 & & \\
\hline & Total & 82.497 & 107 & & & \\
\hline \multirow{3}{*}{ Mean PK } & Between Groups & .468 & 2 & .234 & .417 & .660 \\
\hline & Within Groups & 58.983 & 105 & .562 & & \\
\hline & Total & 59.451 & 107 & & & \\
\hline \multirow{3}{*}{ Mean CK } & Between Groups & 2.551 & 2 & 1.275 & 3.231 & $.043^{*}$ \\
\hline & Within Groups & 41.449 & 105 & .395 & & \\
\hline & Total & 44.000 & 107 & & & \\
\hline \multirow{3}{*}{ Mean TPK } & Between Groups & 2.027 & 2 & 1.014 & 1.982 & .143 \\
\hline & Within Groups & 53.702 & 105 & .511 & & \\
\hline & Total & 55.729 & 107 & & & \\
\hline \multirow{3}{*}{ Mean PCK } & Between Groups & 2.401 & 2 & 1.201 & 2.724 & .070 \\
\hline & Within Groups & 46.286 & 105 & .441 & & \\
\hline & Total & 48.687 & 107 & & & \\
\hline \multirow{3}{*}{ Mean TCK } & Between Groups & 2.112 & 2 & 1.056 & 1.157 & .318 \\
\hline & Within Groups & 95.851 & 105 & .913 & & \\
\hline & Total & 97.963 & 107 & & & \\
\hline \multirow{3}{*}{ Mean TPCK } & Between Groups & 1.838 & 2 & .919 & 1.770 & .175 \\
\hline & Within Groups & 54.513 & 105 & .519 & & \\
\hline & Total & 56.351 & 107 & & & \\
\hline \multirow{3}{*}{ Total Mean TPACK } & Between Groups & .840 & 2 & .420 & 1.524 & .223 \\
\hline & Within Groups & 28.940 & 105 & .276 & & \\
\hline & Total & 29.780 & 107 & & & \\
\hline
\end{tabular}

Note. ${ }^{*} \mathrm{p}<.05$

\section{Findings of the Practice of Teacher Educators' TPACK in terms of Department}

Independent Samples $t$ Test was used to make a comparison between the two departments, academic and education, based on the application level of teacher educators' TPACK because the dependent variable was normally distributed within each population (Morgan, Leech, Gloeckner, \& Barrett, 2011). In fact, there are three main departments in Education Colleges; 
Education, Academic and Co-curriculum. However, the participants from the Co-curriculum department were very few compared to the other two departments. For that reason, the participants of that department were excluded from the study. Then, the participants were divided into two groups (group 1; Academic, and group 2; Education. The results were shown in Table 11.

Table 11. Comparison of the practice of teacher educators' TPACK in terms of their departments ( $n=53$ teacher educators from academic departments and 55 teacher educators from education departments)

\begin{tabular}{|c|c|c|c|c|c|c|}
\hline & Department & $M$ & SD & $t$ & $d f$ & $p$ \\
\hline \multirow[t]{2}{*}{ Mean TK } & 1 Academic & 2.73 & .751 & \multirow{2}{*}{1.854} & \multirow{2}{*}{106} & \multirow{2}{*}{.067} \\
\hline & 2 Education & 2.42 & .967 & & & \\
\hline \multirow{2}{*}{ Mean PK } & 1 Academic & 3.86 & .742 & \multirow{2}{*}{.576} & \multirow{2}{*}{106} & \multirow{2}{*}{.566} \\
\hline & 2 Education & 3.78 & .753 & & & \\
\hline \multirow{2}{*}{ Mean CK } & 1 Academic & 3.68 & .614 & \multirow{2}{*}{.149} & \multirow{2}{*}{106} & \multirow{2}{*}{.882} \\
\hline & 2 Education & 3.66 & .672 & & & \\
\hline \multirow{2}{*}{ Mean TPK } & 1 Academic & 3.33 & .694 & \multirow{2}{*}{.085} & \multirow{2}{*}{106} & \multirow{2}{*}{.933} \\
\hline & 2 Education & 3.31 & .753 & & & \\
\hline \multirow{2}{*}{ Mean PCK } & 1 Academic & 3.85 & .601 & \multirow{2}{*}{-1.613} & \multirow{2}{*}{106} & \multirow{2}{*}{.110} \\
\hline & 2 Education & 4.06 & .730 & & & \\
\hline \multirow{2}{*}{ Mean TCK } & 1 Academic & 3.50 & 1.033 & \multirow{2}{*}{.755} & \multirow{2}{*}{106} & \multirow{2}{*}{.452} \\
\hline & 2 Education & 3.36 & .882 & & & \\
\hline \multirow{2}{*}{ Mean TPCK } & 1 Academic & 2.95 & .682 & \multirow{2}{*}{-2.212} & \multirow{2}{*}{106} & \multirow{2}{*}{$.029 *$} \\
\hline & 2 Education & 3.26 & .741 & & & \\
\hline \multirow{2}{*}{$\begin{array}{c}\text { Total Mean } \\
\text { TPACK }\end{array}$} & 1 Academic & 3.31 & .513 & \multirow{2}{*}{.535} & \multirow{2}{*}{106} & \multirow{2}{*}{.594} \\
\hline & 2 Education & 3.26 & .539 & & & \\
\hline
\end{tabular}

Note. ${ }^{*} \mathrm{p}<.05$

Table 11 showed that teacher educators from education departments were significantly different from those from academic departments in the dimension of TPCK $(p=.029)$. Inspection of the two group means indicated that the mean of TPCK practice of the teacher educators from academic department $(M=2.95)$ was significantly lower than that $(M=3.26)$ of teacher educators from education departments. The difference between the means was 0.31 points on the dimension of TPCK. The effect size $d$ is .04, which is a small size for effects in the behavioral sciences. There were no significant differences between the two groups in other dimensions in addition to the total TPACK (see Table 11). As a consequence, it can be interpreted that the practice of teacher educators' TPACK in their profession did not relate to which department they belong to.

\section{Findings of the Practice of Teacher Educators' TPACK in terms of Gender}

To compare the gender on the practice of teacher educators' TPACK, Independent Samples $t$ Test was used.

The results showed that there was no significant difference in TPACK between the groups divided by gender and even in any dimension of TPACK as well (see Table 12). According to these results, it can be interpreted that the difference in the application level of teacher educators' TPACK in their profession did not relate to gender. 
Table 12. Comparison of the practice of teacher educators' TPACK in terms of gender $(n=12$ males and 96 females)

\begin{tabular}{|c|c|c|c|c|c|c|}
\hline & Department & $M$ & SD & $t$ & $d f$ & $p$ \\
\hline \multirow{2}{*}{ Mean TK } & $1 \mathrm{Male}$ & 2.73 & .957 & \multirow{2}{*}{.515} & \multirow[b]{2}{*}{110} & \multirow[b]{2}{*}{.607} \\
\hline & 2 Female & 2.59 & .899 & & & \\
\hline \multirow{2}{*}{ Mean PK } & 1 Male & 4.08 & .324 & \multirow{2}{*}{1.271} & \multirow{2}{*}{110} & \multirow{2}{*}{.207} \\
\hline & 2 Female & 3.80 & .771 & & & \\
\hline \multirow{2}{*}{ Mean CK } & 1 Male & 3.58 & .580 & \multirow{2}{*}{-.647} & \multirow{2}{*}{110} & \multirow{2}{*}{.519} \\
\hline & 2 Female & 3.70 & .654 & & & \\
\hline \multirow{2}{*}{ Mean TPK } & 1 Male & 3.58 & .598 & \multirow{2}{*}{1.210} & \multirow{2}{*}{110} & \multirow{2}{*}{.229} \\
\hline & 2 Female & 3.32 & .739 & & & \\
\hline \multirow{2}{*}{ Mean PCK } & 1 Male & 4.04 & .551 & \multirow{2}{*}{.425} & \multirow{2}{*}{110} & \multirow{2}{*}{.671} \\
\hline & 2 Female & 3.96 & .685 & & & \\
\hline \multirow{2}{*}{ Mean TCK } & 1 Male & 3.33 & 1.045 & \multirow{2}{*}{-.488} & \multirow{2}{*}{110} & \multirow{2}{*}{.626} \\
\hline & 2 Female & 3.47 & .948 & & & \\
\hline \multirow{2}{*}{ Mean TPCK } & 1 Male & 3.05 & .891 & \multirow{2}{*}{-.488} & \multirow{2}{*}{110} & \multirow{2}{*}{.627} \\
\hline & 2 Female & 3.15 & .710 & & & \\
\hline \multirow{2}{*}{$\begin{array}{l}\text { Total Mean } \\
\text { TPACK }\end{array}$} & 1 Male & 3.38 & .435 & \multirow{2}{*}{.498} & \multirow{2}{*}{110} & \multirow{2}{*}{.619} \\
\hline & 2 Female & 3.30 & .543 & & & \\
\hline
\end{tabular}

\section{DISCUSSION}

One of the findings of this study uncovered that the application level of teacher educators' technological pedagogical content knowledge (TPACK) had no significant difference among the selected Education Colleges.

Moreover, the results revealed that different years of teaching service and different degrees of teacher educators could not make any difference in applying overall TPACK in their teaching, but made a different level in using technological knowledge. These results were consistent with the findings of Jang and Chang (2016) which showed that there was no significant difference in overall TPACK of physics instructors according to academic degrees but not in line with one of his findings that indicated the statistical significance in overall TPACK according to their teaching experience. Moreover, the result of Ozudogru and Ozudogru (2019) which showed no significant effect on TPACK by the year of teaching experience and significant difference on technological knowledge subscale was consistent with the finding of this study. On the contrary, Akturk and Ozturk (2019) found that professional experience of teachers made a significant difference in their TPACK levels.

Likewise, one of the results highlighted that although various levels of teacher educators' rank could not make any contrast on utilizing overall TPACK, they brought about a different applying level of technological knowledge and content knowledge. Besides, working in different departments gave rise to various application levels in the technological pedagogical content knowledge (TPCK) subscale but not in all subscales of TPACK. The last finding which is concerned with the gender of the participants showed that there was no significant difference in not only using overall TPACK of teacher educators but also applying knowledge of each dimension. This finding was in line with many findings which reported that there was no significant difference in the overall TPACK of instructors/teachers in terms of gender (Akturk \& Ozturk, 2019; Jang \& Chang, 2016). In contrast, the result of Ozudogru and Ozudogru (2019) which showed significant differences between gender was not consistent with the result of this study.

Furthermore, in comparing the means of teacher educators' TPACK, it was found that the teacher educators' application levels of CK, PK and PCK were higher than TK, TCK, TPK and TPCK levels. This result was not deviated from the findings of Akturk and Ozturk (2019) which 
indicated that CK and PCK levels of teachers were at good levels and the levels of TK, PK, TPK, TCK and TPACK were moderate. Likewise, Alqurashi et al. (2016) mentioned in their paper that pedagogy and pedagogical content knowledge were the highest mean scores and technology and technological pedagogy knowledge were the lowest mean scores of all the domains in studying teachers in USA and Saudi Arabia. This was in line with the result of this study.

In addition, those groups of teacher educators who had the lowest and highest years of teaching service applied their TPACK lower than the other two groups. In addition, it was found that teacher educators who had higher educational level applied TPACK more than those who had lower educational attainment. What is more, the result mentioned that pedagogical content knowledge of teacher educators increased gradually with respect to their teaching experience and the young teacher educators applied much more technological knowledge than the elders. This is consistent with the result of Akturk and Ozturk (2019) that showed teachers who have low teaching experience has higher TK than teachers who have been working for 21 years or more.

The reason why teacher educators have lower TPACK level (as means showed that they sometimes used their TPACK in their teaching) may be that there is still lack of infrastructure in both public schools and universities, especially access to technology. Another point is that the teachers from both basic and higher education did not have much opportunity to be familiar with technology. The next problem is that most teachers from Myanmar have many obstacles to use learner centered approach till now. The reason may be because of the large class size, lack of materials, insufficient teachers.

Dysart and Weckerle (2015) stated in his paper that new teachers entered into teaching profession as experts in their discipline at the university or college level, but did not always have experience with pedagogical techniques or technological tools. The same situation takes place in Myanmar as well. It is undeniable that most teachers lack experience in both except those who graduated from the Universities of Education. But, even they still have insufficient technological knowledge. Thus, it is obvious that insufficient pedagogical and technological knowledge in teachers before their profession is one of the main reasons.

\section{CONCLUSION}

This study was carried out to investigate the TPACK-based practice of teacher educators from the Education Colleges. The findings revealed that the teacher educators applied their knowledge related to technological subscales lower than pedagogical content knowledge subscales in their teaching. In details, teacher educators rarely applied their technological knowledge in their teaching but other dimensions of TPACK were put into practice on some occasions. However, the findings revealed that there was no significant difference in the practice of overall Technological Pedagogical Content Knowledge among the teacher educators in terms of their Education College, experience, academic degree, rank, department and gender. On the contrary, different applying levels of technological knowledge were found among those teacher educators with regards to their teaching experiences, degrees and ranks. In addition, there were also significant differences of practices among those in content knowledge subscale with respect to their ranks and in the seventh subscale, technological pedagogical content knowledge, with respect to their departments as well. According to the results, it was disclosed that pedagogical content knowledge of teacher educators became higher with the increase of their experience. Moreover, the findings of this study highlighted the need to upgrade the TPACK level of teacher educators in Education Colleges in Myanmar to be effective in their profession. 


\section{RECOMMENDATIONS}

It is assured that the integration of technology in teaching provides a considerable support to the learning and teaching processes. Teacher educators who train prospective teachers should integrate pedagogical approaches and technology in their teaching which will assist student teachers to have a better understanding of the content and educational practices. It means that teacher educators' TPACK-based practices can encourage teacher candidates to apply these practices in their profession later. Thus, professional development programs related to technology and pedagogy trainings should be conducted as a mandatory for teacher educators in education colleges. Moreover, to be able to apply TPACK-based practices during teaching, the courses which emphasize TPACK should be specific in the curricula of teacher education and learning environments which provide more opportunity for the pre-service teachers to practice.

\section{LIMITATIONS}

Although this study focused on the TPACK practice of teacher educators from three Education Colleges, Yangon Region in Myanmar, further researches should be carried out in other Education Colleges and Academic Universities and in Basic Education Schools as well. Furthermore, as this research was a quantitative study, a qualitative study related to teachers' TPACK should be carried out to have a deeper understanding on that issue.

\section{REFERENCES}

Akturk, A. O., \& Ozturk, H. S. (2019). Teachers' TPACK levels and students' self-efficacy as predictors of students' academic achievement. International Journal of Research in Education and Science, 5(1), 283-294.

Alqurashi, E., Gokbel, E. N., \& Carbonara, D. (2016). Teachers' knowledge in content, pedagogy and technology integration: a comparative analysis between teachers in Saudi Arabia and United States. British Journal of Educational Technology, 1-13. https://doi.org/10.1111/bjet.12514

Angeli, C., \& Valanides, N. (2015). Technological pedagogical content knowledge exploring, developing, and assessing TPCK. New York: Springer. https://doi.org/10.1007/978-14899-8080-9

Can, B., Erokten, S., \& Bahtiyar, A. (2017). An investigation of pre-service science teachers' technological pedagogical content knowledge. European Journal of Educational Research, 6(1), 51-57. https://doi.org/10.12973/eu-jer.6.1.51

Cohen, J. (1988). Statistical power analysis for the behavioral sciences (2nd ed.). New York: Lawrence Erlbaum Associates.

Doering, A., Veletsianos, G., Scharber, C., \& Miller, C. (2009). Using the technological, pedagogical, and content knowledge framework to design online learning environments and professional development. J. Educational Computing Research, 41(3), 319-346. https://doi.org/10.2190/EC.41.3.d

Dysart, S., \& Weckerle, C. (2015). Professional development in higher education: A model for meaningful technology integration. Journal of Information Technology Education: Innovations in Practice, 14, 255-265. https://doi.org/10.28945/2326 
Goradia. (2018). Role of educational technologies utilizing the TPACK framework and 21st century pedagogies: Academics' perspectives. IAFOR Journal of Education, 6(3), 43-61. https://doi.org/10.22492/ije.6.3.03

Jang, S.-J., \& Chang, Y. (2016). Exploring the technological pedagogical and content knowledge (TPACK) of Taiwanese university physics instructors. Australasian Journal of Educational Technology, 32(1), 107-121. https://doi.org/10.14742/ajet.2289

Karaca, F. (2015). An investigation of preservice teachers' technological pedagogical content knowledge based on a variety of characteristics. International Journal of Higher Education, 4(4), 128-136. https://doi.org/10.5430/ijhe.v4n4p128

Keser, H., Yılmaz, F. G. K., \& Yılmaz, R. (2015). TPACK competencies and technology integration self-efficacy perceptions of pre-service teachers. Elementary Education Online, 14(4), 1193-1207. https://doi.org/10.17051/io.2015.65067

Kiray, S. A. (2016). Development of a TPACK self-efficacy scale for preservice science teachers. International Journal of Research in Education and Science (IJRES), 2(2), 527-741. https://doi.org/10.21890/ijres.64750

Koehler, M. J., \& Mishra, P. (2009). What is technological pedagogical content knowledge? Contemporary Issues in Technology and Teacher Education, 9(1), 60-70.

Kou, N. C. (2015). Action research for improving the effectiveness of technology integration in preservice teacher education. I.e.: Inquiry in Education, 6(1), 1-19.

Loughran, J., Berry, A., \& Mulhall, P. (2012). Understanding and developing science teachers' pedagogical content knowledge (2nd ed.). AW Rotterdam: Sense Publishers. https://doi.org/10.1007/978-94-6091-821-6

Mishra, P., \& Koehler, M. J. (2006). Technological pedagogical content knowledge: A framework for teacher knowledge. Teachers College Record, 108(6), 1017-1054. https://doi.org/10.1111/j.1467-9620.2006.00684.x

Morgan, G. A., Leech, N. L., Gloeckner, G. W., \& Barrett, K. C. (2011). IBM SPSS for introductory statistics: use and interpretation (4th ed.). New York: Taylor and Francis Group, LLC.

Nordin, H., \& Ariffin, T. F. T. (2016). Validation of a technological pedagogical content knowledge instrument in a Malaysian secondary school context. Malaysian Journal of Learning and Instruction, 13, 1-24. https://doi.org/10.32890/mjli2016.13.1.1

Özdemir, M. (2006). An examination of techno-pedagogical education competencies (TPACK) of pre-service elementary school and preschool teachers. Journal of Education and Training Studies, 4(10), 70-78. https://doi.org/10.11114/jets.v4i10.1816

Ozudogru, M., \& Ozudogru, F. (2019). Technological pedagogical content knowledge of mathematics teachers and the effect of demographic variables. Contemporary Educational Technology, 10(1), 1-24. https://doi.org/10.30935/cet.512515

Padmavathi, M. (2017). Preparing teachers for technology based teaching learnign using TPACK. I-Manager's Journal on School Educational Technology, 12(3), 1-9. https://doi.org/10.26634/jsch.12.3.10384

Sahin, I. (2011). Development of survey of technological pedagogical content knowledge (TPACK). The Turkish Online Journal of Educational Technology, 10(1), 97-105. 
CONTEMPORARY EDUCATIONAL TECHNOLOGY, 2020, 11(2), 159-176

DOI: https://doi.org/10.30935/cet.660829 - TYPE: Research Article

Shulman, L. S. (1986). Those who understand: Knowledge growth in teaching. Educational Researcher, 15(2), 4-14. https://doi.org/10.3102/0013189X015002004

Shulman, L. S. (1987). Knowledge and teaching: Foundations of the new reform. Harvard Educational Review, 57(1), 1-23. https://doi.org/10.17763/haer.57.1.j463w79r56455411

Correspondence: Win Thinzarkyaw, PhD Candidate, School of Education, Central China Normal University, Wuhan, China. E-mail: winthinzarkyaw@mails.ccnu.edu.cn 